\title{
Modada Melezleşme Olgusu ve Japon Moda Tasarımcıları Örneği
}

Arş. Gör. Şakir Özüdoğru

Makale Geliş Tarihi: 0I.12.2016

Yayına Kabul Tarihi: 05.04.2017

\section{Özet}

Bu çalışmada, modada melezleşme olgusu, Batı dünyası dışından Fransız moda sistemine kabul edilen ilk tasarımcılar olan Japon moda tasarımcıları bağlamında sorgulanmaktadır. Japon moda tasarımcıları örneği kültürel melezleşme yaklaşımları çerçevesinde ele alınmıştır. Bu çalışma ele aldığı olguya dair cevaplar üretmeyi amaçlamamaktadır; aksine söz konusu olguya farklı açılardan yaklaşarak sorular sorma ve bu yolla günümüzde yaygın bir eğilim haline gelmiş olan uluslararası moda sahnesinde ulusal/kültürel kimliğe vurgu yapma eğilimine dair akademik bir ilgi uyandırma niyetindedir.

Anahtar Kelimeler: Küresel Moda, Japon Moda Tasarımcıları, Melez Moda, Ulusal Kimlikler

\section{HYBRIDIZATION IN FASHION AND JAPANESE FASHION DESIGNERS}

\section{Abstract}

This study aims to interrogate the fact of hybridization in fashion in the context of Japanese fashion designers. These designers were the first outsiders included by the French fashion system. In this study, the case of Japanese fashion designers is discussed in the frame of approaches to cultural hybridization. The aim of the study is not to find certain answers; on the contrary, this study aims to question the fact of hybridization in fashion from various perspectives and intends to inspire an academic interest in the trend of expressing national/cultural identity in the international fashion scene, which has become a common trend in the current period.

Keywords: Global Fashion, Japanese Fashion Designers, Fusion Fashion, National Identities 


\section{Giriş}

1990'lardan bu yana, küreselleşmenin artan etkisi ile birlikte, yaratıcı endüstriler ülkelerin imajlarını oluşturmalarında giderek daha önemli bir yer tutmaya başlamıştır. Bu endüstrilerden biri olan moda endüstrisi, birçok ülkenin yaratıcı imajını öne çıkarmasının yanında önemli bir ulusal gelir kaynağıdır. Moda tasarımcıları ve firmalar, uluslararası moda sahnesinde kendilerini görünür kılmanın ve farklılaşmanın yollarını aramaktadır. Bu sahnede, son dönem oldukça rağbet gören eğilimlerden biri de yerel/ulusal kimliklere yönelimdir (Teunissen, 2005). Bu durum, kültürel küreselleşmenin uluslararası moda sahnesindeki veçhelerinden biridir. Kültürel küreselleşmeye dair yaklaşımları iki temel görüş etrafında ele almak olasıdır. Bir yanda kültürel küreselleşmenin Batılı ülkelerin ve şirketlerin tahakkümü altında olduğu ve kültürel küreselleşme söyleminin Batı sömürgeciliğinin yeni bir biçiminden başka bir şey olmadığı görüşü vardır. Bu görüşe göre, moda da Batı sömürgeciliğinin bir biçimidir. Batı, kendi tüketim alışkanlıklarını moda aracılığıyla dünyaya yaymaktadır. Bunu yaparken Üçüncü Dünya'nın ucuz iş gücünden, Üçüncü Dünya ülkelerinin yönetimlerine zorla kabul ettirdiği ekonomik imtiyazlardan faydalanmakta ve hem üretimini bu ülkelerde yaptırmakta hem de bu ülkeleri bir pazar olarak kullanmaktadır. Batı modasının kitle iletişim araçları sayesinde dünyanın geri kalanına empoze ettirilmesi kültürel çeşitliliği ortadan kaldırmakta ve yerel zanaatları ve işçiliği öldürmektedir (Schiller, 1979). Bu görüşün karşı kutbunda yer alan görüşe göre ise, kültürel küreselleşmenin insanlar arasındaki etkileşimi arttırdığını, empatiyi güçlendirdiğini ve ortak bir dünya bilinci oluşturmaya katkıda bulunduğunu iddia etmektedir. Bu görüşe göre, modaların dünyaya yayılması, kültürel çeşitliliği azalmaktan ziyade daha çok sayıda kültürün dünya üzerinde görünür olmasını sağlayacak ve bu da kültürlerin etkileşimine olanak verecektir (Tomlinson, 2004).

Moda çalışmaları alanında, 1980'lerden bu yana, Batılı moda sisteminin uluslararası geçerliliği ve bu sistemin dışında başka moda sistemlerinin var olup olmadığı sorgulanmaktadır. Buna ek olarak, Batılı moda sistemi 20. yüzyılın büyük bir kısmında tutucu bir karakter sergilemesine karşın, Batı dünyası dışından gelen moda tasarımcılarına ve firmalara kapılarını açmaya başlamıştır. Daha önce değinildiği gibi, Batı dünyası dışından gelen moda tasarımcıları ve firmalar, moda mega-kentleri Paris, Londra, Milano ve New York gibi kentlerde düzenlenen moda etkinliklerinde sıkça ülkelerinin ve kültürlerinin kendine özgü özelliklerine vurgu yapan ve bu özellikleri 
uluslararası moda eğilimleri ile birleştiren koleksiyonlar sunmaktadırlar. Bu durum, kültürel küreselleşmenin ana unsurlarından biri olan melezleşme olgusunu akla getirmektedir. Homi Bhabha (1994), melezleşmeyi kültürel farklıııkların bir araya geldiği ve çatıştığı bir alan olarak tanımlamaktadır. Bu alanda, değişmez olduğu varsayılan kimlik inşalarının düzeni bozulmakta, geçmiş ve gelecek, içerisi ve dışarısı gibi ikili karşıtlıklar sorgulanmaktadır. Moda tasarımcılarının dünyanın moda mega-kentlerinde sunduğu, kendi özgün kültürel karakterlerine vurgu yapan ve bu özellikleri Batılı moda eğilimleri ile harmanlayan koleksiyonlar melezleşmenin uluslararası moda sahnesindeki görünür yüzüdür.

Bu çalışmanın amacı, modada melezleşme olgusunu Batılı moda sistemine Batı dünyası dışından ilk kabul edilen tasarımcılar olan Japon moda tasarımcıları örneği bağlamında sorgulamaktır. Japon moda tasarımcıları örneği, kültürel melezleşme yaklaşımları çerçevesinde ele alınmıştır. Şunu belirtmekte fayda vardır ki, bu çalışma ele aldığı olguya dair cevaplar üretmeyi amaçlamamaktadır; aksine, söz konusu olguya farklı açılardan yaklaşarak sorular sorma ve günümüzde yaygın bir eğilim haline gelmiş olan bu olguya dair akademik bir ilgi uyandırma niyetindedir.

\section{Kurumsallaşmış Modern Moda Sisteminin Ortaya Çıkması ve Gelişimi}

Avrupalı sömürgecilerin anlatılarının ve bu anlatıların şekillendirdiği erken dönem sosyal bilimlerin etkisiyle, moda uzun bir süre boyunca bu alanda çalışmalarını sürdüren araştırmacılar ve sosyal bilimciler tarafından Avrupa modernleşmesinin ve kapitalizminin ortaya çıkardığı bir olgu olarak ele alınmıştır (Craik, 1993; Davis, 1997; Jansen, 2013; Kaiser, 2012). Modayı, Batı kapitalizminin ve sömürgeciliğinin bir ürünü olarak açıklayan kuramlar modanın doğuş yerini 13. yüzyıl sonları ve 14. yüzyılın Burgonya bölgesi olarak işaret etmektedir. Fred Davis'e (1997: 72-73) göre, bu bölgede Doğu ile girilen ticari ilişkiler sayesinde giderek zenginleşen şehir burjuvazisi ve aristokrasi arasında giyim kuşam nesneleri "haset duygusuna dayalı bir statü rekabetinin simgesel araçları hâline gelmiştir".

Paris, uzun bir süredir modanın merkezi olarak kabul edilmektedir (Steele, 1998). Bu kabulün birçok nedeni arasından en önemlileri, Fransa'da 1638 ile 1715 yılları arasında hüküm süren 14. Louis'nin modaya dair yaklaşımı ve imparatorluğun finans bakanı Jean-Baptiste Colbert'in tekstil ve giyim ürünleri üzerine geliştirdiği ekonomi politikalarıdır. Söz konusu iki tarihi figür, Paris'in modanın sembolü hâline gelmesinde hayati bir öneme sahip 
olmuştur (Kawamura, 2004). Takip eden yüzyılda, Paris'te her yönden birbirini destekleyen kurumsal bir moda sistemi ortaya çıkmıştır. Moda sosyoloğu Yuniya Kawamura'nın (2004) adlandırmasıyla kurumsallaşmış modern moda sistemi olarak tarif edilebilecek bu sistem; üretim alanında terziler, moda tasarımcıları, küçük ya da büyük ölçekli üretim yapan firmalar; tüketim alanında yeni ürünlere yönelik talep oluşturan ve bu ürünleri özgürce tüketebilen tüketiciler; ayrıca üretim ve tüketim arasında denge sağlayan, moda tasarımcılarının ve firmaların moda sektörüne hangi şartlar altında girebileceğini organize eden bir örgüt ve bunların tüketiciler arasında tanınırlığını sağlayan bir medya ağından oluşmaktadır.

Fransa'da, moda sektörünü belirleyen, moda sahnesinde kimin hangi şartlarda yer alacağına karar veren kurum, üye kabulünde çok ağır şartlara sahip olan Paris Haute Couture Sendikası (La Chambre Syndicale de la Counture Parisienne) olagelmiştir (Kawamura, 2004). Organizasyon, İkinci Dünya Savaşı'nın getirdiği yıkım, savaş teknolojilerinin sanayiye aktarılmasıyla gelen yüksek teknolojili üretim ve iletişim teknolojilerindeki gelişmeler nedeniyle, Paris'in uluslararası moda sahnesindeki üstünlüğünü koruyabilmesi için, üyelik şartlarında çeşitli düzenlemeler yapmış; 1973 yılında üyelik şartlarını yumuşatmış ve hazır giyim ve erkek giyimi sektöründe yer alan firmaların, Hazır Giyim Sendikası ve Erkek Modası Sendikası altında organizasyona üye olabilmelerine imkân tanımışsa da organizasyonun üye sayısı maliyetlerden dolayı giderek azalmıştır (Crane, 2003).

Pazarın büyümesi ve rekabet şartlarının zorlaşması durumuna firmalar ve tasarımcılarılar iki farklı strateji izleyerek cevap vermiştir. Birinci strateji, "sürekliliği, tahmin edilebilirliği ve zarafet"i önemseyen, lüks giyim ve haute couture firmalarının izlediği "sanatçı-zanaatkâr" stratejisidir (Crane, 2003). Bu firmalar organizasyon olarak oldukça büyük olduklarından ve belirli bir müşteri kitlesini elinde bulundurduklarından hâlihazırdaki müşteri kitlesini kaybetmek istememektedirler. Bu nedenle, radikal değişikliklere gitmek yerine marka imajlarını koruyabilecekleri ve kendi tarzlarını devam ettirebilecekleri zanaatkârlığı ön plana çıkaran tasarımlar sunmak onlar için deneyselliği ya da eğlence unsurunu öne çıkaran kavramsal çalışmalardan daha önemlidir (Sproles, 1981). Haute couture defilelerinin çoğunluğu artık firmanın imajını sürdürmesi için gerçekleştirilmektedir ve ekonomik getiriden çok bir prestij unsuru halini almıştır. Kaliteli ve tasarım temelli hazır giyim olarak Türkçeleştirilen ancak kitle üretimine yönelik hazır giyim 
üretiminden farklı olan pret-a-porter ve kozmetik ürünler günümüzde moda sektöründe yer alan bu tip firmaların gelirinin büyük bir kısmını oluşturmaktadır (Crane, 2003; Kawamura, 2004).

Büyük firmaların izlediği süreklilik stratejisinin aksine, pazarın büyümesi ve uluslararası tanınırlık için büyük yatırımların gerekmesi modaya yenilikçi ve sıra dışı yaklaşımları ile ilgi çekmeyi başaran yeni bir moda tasarımcısı tipini öne çıkarmıştır. Belirli kavramsal kategoriler altında incelenebilecek ancak her biri kendine özgü stratejiler kullanan bu tasarımcılar grubu genellikle organizasyon tarafından kabul edilmek isteyen ve pret-aporter'ın organizasyon tarafından desteklenmeye başlamasıyla dünya çapında tanınmışlık elde etmeyi başaran bir dizi tasarımcıdan oluşmaktadır. Tasarımlarını bu yaklaşımla üreten moda tasarımcıları, créateur olarak isimlendirilmektedir. Bu makalenin odağını oluşturan Japon moda tasarımcıları da créateur olarak isimlendirilen bu tasarımcı kategorisine dâhildir.

\section{Kurumsallaşmış Modern Moda Sistemi ve Japon Moda Tasarımcıları}

1970'lerde Paris'te koleksiyonlarını sergilemeye başlayan Japon kökenli Issey Miyake ve 1980'lerde onu takip eden Yohji Yamamoto ve Comme des Garçons firmasının kurucusu Rei Kawakbo créateur'lar arasında yer almaktadırlar. Japon tasarımcıların bu çalışmadaki önemi organizasyona Avrupa dışından kabul edilen ilk tasarımcılar olmalarından gelmektedir (Kawamura, 2004). Tasarımlarında; Japon geleneklerinden, tekstil teknolojilerindeki yeni gelişmelerden ve güncel görsel sanatlardan yararlanan bu tasarımcılar, Batı moda sisteminin dışına çıkan, güncel moda eğilimlerine uymayan kendi özgün tarz ve yaklaşımlarını geliştirdikleri tasarımlarla tanınmışlardır.

Japon moda tasarımcılarının estetik yaklaşımı bazı moda yazarı tarafından 'sefalet estetiği' olarak tanımlanmaktadır (English, 2007: 117). Kurumsallaşmış modern moda sistemi, ortaya çıktığı 19. yüzyıl ortalarından 1960'lara kadar özellikle üst sınıflara hitap etmiş ve mükemmelliği, kusursuzluğu, kalitesi ve zanaatkârların hatasız işçiliği ile tanınmıştır. İkinci Dünya Savaşı sonrası Japonya'sında yetişen Japon tasarımcılar, yetiştikleri dönemin hatıralarını ve hissiyatını taşımaktadırlar. 1980'lerin başlarında Rei Kawakubo'nun Paris'te düzenlediği bir defilede mankenler siyah kıyafetler içinde, kafaları tıraş edilmiş biçimde ya da kirli ve dağınık saçlarla ve soluk yüzlerle podyuma çıktıklarında tasarımcı, moda basını tarafından "paçavra 
toplayıcısı" olarak isimlendirilmiş ve söz konusu defile, Batılı moda basını tarafından politik bir gösteri olarak karşılanmıştır (English, 2007). Moda basınının Rei Kawakubo'nun tasarımlarını böyle sert bir şekilde eleştirmesinin nedeni, bu tasarımların Batılı moda geleneğine tamamen zıt olan yapısıdır. Kawakubo, tasarımlarında mükemmel işçilik ve kusursuz son ürün anlayışının karşısına yarım bırakılmış izlemini veren, her tarafı deliklerle dolu kıyafetler koymuştur. Kawakubo'nun sıklıkla kullandığı diğer bir unsur da üç kollu ceketler, neresinden giyileceği belli olmayan kazaklar, bir tarafı diğerinden uzun ceketlerle örneklenebilecek asimetridir.

Sözü edilen üç Japon moda tasarımcısı da tasarımlarında eski Japon geleneklerini ön plana çıkarmışlar ve Japon giyiminin bir yapıtaşı olan kimonodan yola çıkarak çeşitli tasarımlar üretmişlerdir. Batılı modern moda sistemi ortaya çıktığı zamandan beri sınıflar, cinsiyetler ve ırklar arasındaki ayrıma dayandırımaktadır (Vinken, 2005). Kimono ise cinsiyet ayrımını ortadan kaldırmakta, beden hatlarını yok etmekte, giysiyi giyenin cinsiyetini belirsizleştirmektedir. Kawakubo, modern modanın bu yönüne dikkat çekerek, modanın kadın bedenini vurgulamak yerine insanların oldukları gibi görünmelerine izin vermesi gerektiğini iddia etmektedir (English, 2007). Issey Miyake ise tasarımlarının kaynağını baştan beri kimono olarak almış, Japonya'da hâlâ geleneksel yollarla üretim yapılan bölgelerden kumaşlar toplamış ve bunlarla bir dizi kimono tasarımı üretmiştir (Hiramitsu, 2005). Bu tasarımcılar aynı zamanda geleneksel Japon motiflerini, süslemelerini ve baskılarını kumaş yüzeylerinde kullanmaktadırlar.

Jennifer Craik (1993: 41), modadaki Japon etkisinin bedenin Batı'ya ait ideallerini sorguladığının, yeni bir beden-mekan ilişkisi kurduğunun ve alışılmış giyim alışkanlıklarını değiştirdiğinin altını çizmektedir. Japon moda tasarımcıların modaya getirdiği yenilikler birkaç maddede ifade edilebilir. ilk olarak, bu tasarımcılar yönlerini moda sistemini kendisine çevirmiş, Japon geleneklerinden aldıkları unsurlarla modern Batı moda sistemini analiz etmiş ve eleştirmişlerdir. Japon moda tasarımcıları modanın her sezon yenilenen görünümünün karşısına kalıcı, giyeniyle uyum içinde olan tasarımlar koymuşlardır. Ayrıca, Japon moda tasarımcıları Batılı moda anlayışının kusursuz işçilik idealine saldırmışlardır. Bu tasarımcılara ait diğer bir özellik ise tasarımlarının politik, sosyal ve iletişimsel anlamlar taşımasıdır. Sözü edilen tasarımcılar; defilelerinde kullandıkları dekor, makyaj, koreografi gibi unsurlarla Hiroşima ve Nagazaki'de yaşanan dehşete göndermeler yapmışlardır. Son olarak, Japon moda tasarımcılarının ürettikleri tasarımlar, 
izleyenlerini şok ederek moda sistemini sorgulamaya çağırmaktadır.

Modanın mega başkenti Paris, Japon moda tasarımcıları ile ilk defa Batılı moda anlayışının Batı dünyası dışından gelen tasarımcılar tarafından sorgulanmasına tanık olmuştur. Bununla beraber, Batılı moda basını, bu tasarımcıların etnik kökeni üstünde ısrarla durmuş ve sıklıkla Japonluklarına vurgu yapmıştır. Kawamura (2004) Japon moda tasarımcılarının, etnik kimliklerini Fransız moda sistemine girmekte bir strateji olarak kullandıklarının altını çizmektedir. Etnik kimlik etrafında inşa edilen tasarımlarla uluslararası moda sahnesinde görünür olma eğilimi Japon moda tasarımcılarının ardından özellikle 1990'larda artmış göstermiş; birçok Asya, Güney Amerika ve Afrika kökenli tasarımcı dünya moda sahnesine kendi yerel kültürlerine ve ulusal tarihlerine yaptıkları vurguyla çıkmaya çalışmışlar ve çalışmaktadırlar. Japon moda tasarımcıları ile başlatılabilecek bu durumun günümüzde yaygın bir eğilim haline gelmiş olması, José Teunissen'in (2005: 21) modanın kavramlarını yeniden tanımlama çağrısını akla gelmektedir. Artık küresel bir dünyada yaşadığımız ve küreselleşmenin getirisi olan karşııılı bağlantılııı (Tomlinson, 2004) düşünüldüğünde moda olgusunun bundan payını almamış olması imkânsızdır. Ancak, moda bazı yazarların iddia ettiği gibi özgürleşmiş midir? Artık, Batı'nın modadaki üstünlüğünden söz etmek imkânsız mıdır? Moda merkezleri çeşitlenmiş ve moda sektörü Batı dışındaki ülkeler için de kârlı bir sektör haline gelmiş midir? Ulusal ve etnik kimliğe yönelim, unutulan el işçiliğini ve kültürel değerleri gün yüzüne çıkarma gücü taşımakta mıdır? Bu sorular, Batıı moda sisteminin dışında var olan başka moda sistemi ya da moda sistemleri var mıdır ya da moda olgusu Batı kapitalizmi ve sömürgeciliğinin ortaya çıkardığı bir unsur mudur sorusu altında cevaplanmayı bekleyen sorulardır.

Kawamura'nın (2004) Japon moda tasarımcıları üzerine yürüttüğg̈ araştırmada, Japon moda tasarımcılarının Fransız moda sistemi içindeki varlığına dair çelişkili bir durum ortaya çıkmaktadır. Bu araştırmaya göre, Batılı basın, Japon moda tasarımcılarını Japon kimlikleri ile ön plana çıkarmakta ve gerçekleştirdikleri her defilenin ardından onların Japon oluşuna dair vurgu yapmaktadır. Öte yandan, Japon moda tasarımcıları, Japon olmalarının tasarımlarını etkilemediğini, tasarımlarını evrensel bir moda dilinde ürettiklerini ve her seferinde Japon olarak işaret edilmekten hoşlanmadıklarını dile getirmektedirler. Bu durum Doreen Massey (1994: 149) üç geometrisi kavramını akla getirmektedir. Yazara göre, 
Bazı insanlar küreselleşmeyi diğerlerinden daha fazla kontrol edebilmekte; akışları ve hareketleri sadece bir kısım başlatmakta; bazıları daha çok küreselleşmenin alıcı ucunda yer almakta; bazıları da küreselleşme tarafından etkili bir biçimde hapsedilmiş durumdadır. (Tomlinson, 2004)

Japon moda tasarımcılarına neden Paris'e gittikleri sorulduğunda, Japonya'da modanın değer görmediğini söylemekte ve eğer dünya çapında ünlü bir moda tasarımcısı olmak istiyorlarsa Paris'e gitmek zorunda olduklarının altını çizmektedirler. Bu tasarımcılardan biri olan Issey Miyake, özellikle İkinci Dünya Savaşı'ndan sonra Batı değerleri ile büyüyen ilk kuşak olduklarını, Batı'nın yönünün yeni bir kimlik inşa etmek için doğru yol olduğuna inandıklarını söylemekte ve söz konusu moda olunca Avrupa geleneğine saygı duyduğunu, çünkü Batılıların bunu daha iyi yaptığını düşündüğünün altını çizmektedir (Cocks, 1986). Bunun yanında, Paris'te faaliyet gösteren birçok Japon tasarımcı aynı zamanda Japonya'da da ürünlerini satmaktadır; ancak Paris'te olmak onlar için farklı ve daha güçlü bir imaj sunmaktadır. Kawamura'nın (2004: 99) etnografik araştırması sırasında görüşme yaptığı Miyake'nin asistanlarından biri, müşterilerinin yüzde 75'nin Japon olduğunu söylemekte ve bu durumu şöyle açıklamaktadır:

Müşterilerimin nereden geldiği benim için hiç önemli değil. Japonya'dan, Suudi Arabistan'dan, Asya'dan ya da Afrika'dan olabilirler. Bütün Japonya' dan müşterilerim var, kırsal kesimden bir kadın müşterinin benim tasarımlarımı ve 'Made in France' etiketini görünce dikkat kesildiğini söylüyorlar. Paris'te yaşayan bir Japon'un tasarladığı bir şeyi giymek onu iyi hissettiriyor. Bu nedenle Paris'te olmam benim için önemli.

Ürünün Paris'te tasarlanmış ya da üretilmiş olması çoğu zaman ürünün kendisinden daha önemli bir hâle gelebilmektedir. Aynı görüşmeci, Japon müşterilerin Fransız moda sisteminde var olan bir Japon'un tasarımlarını satın almaktan gurur duyduğunu belirtmektedir. Bu noktada Paris'in Japon moda tasarımcıları için sembolik bir sermaye olduğu söylenebilir. Pierre Bourdieu'nun (1984) kültürel sermaye ve sembolik sermaye üstüne söyledikleri kentlere de uygulanabilir. Buna göre, kültürel sermaye bireylerin beğeni ve güzellik algılarını, toplum içinde nerede konumlandıklarını belirlemektedir. Bunu günümüz küreselleşen dünyasına kentler bazında uygulayacak olursak, bir kentin sahip olduğu tarihi, sanatsal, düşünsel ürünler toplamının o kentin kültürel sermayesini arttıracağı söylenebilir. Tarih boyunca birçok kentin "geçmişin sanat hazinelerini ve kültür miraslarını 
içeren kültür merkezleri olduğu" varsayılmaktadır (Featherstone, 2005: 160). Paris de kuşkusuz bu kentlerden biridir. Moda sektöründe ise yukarıda da ele alındığı gibi, Paris'in diğer kentlere göre bir üstünlüğü vardır. Yanı sıra, Mike Featherstone'un (2005) belirttiği gibi, bu kentler yayıncılıktan sanata, turizmden sinemaya birçok sektörü içinde barındırdığı için kültürel olanın ekonomik bir kazanıma dönüşmesinde de işlev görmektedir.

Bourdieu (1984), sosyal sermayeyi kişilerin içinde bulunduğu sosyal ağlar ve ilişkiler olarak tanımlamaktadır. Allen J. Scott'ın (2001) işaret ettiği gibi, büyük metropoller içinde birbiri ile bağlantılı olan birçok sektörün iş yaptığı dolayısıyla ilişki içinde olduğu uzamlardır. Bu uzamlarda birbirine benzer alanlarda kültürel ürünler veren, sektöre dâhil olan kişiler ve kuruluşlar hem yardımlaşma hem rekabet içindedirler. Bu nedenle, metropoller sosyal sermaye açısından zengin yerlerdir. Japon moda tasarımcıları örneğinde bu durum iki şekilde karşımıza çıkmaktadır. Birincisi, Kawamura'nın (2004) çalışmasında vurgulandığı gibi, Paris'teki tekstil ve konfeksiyon işinde çalışanlar daha yetenekli ve bilgilidir. Tasarım ofislerini Paris'te konumlandırmak, Japon moda tasarımcılarının eğitimli iş gücüne daha kolay ulaşabilmelerinin bir yoludur. Aynı zamanda, sözü edilen tasarımcılar birbirini tanımakta, Fransız moda sistemi içinde birbirine destek çıkmaktadırlar. Sözü edilen üç tasarımcıdan sonra Paris'te moda evi açan birçok Japon moda tasarımcısı ilk önce bu üç tasarımcının yanında çalışmış, onların sosyal ortamı sayesinde moda basını ve sektörden diğer kişilerle tanışma fırsatı bulmuştur (Kawamura, 2004). Bourdieu'ya (1984) göre, sembolik sermaye kültürel, sosyal ve ekonomik sermayenin bir toplamı olarak işlev görmektedir. Paris, Japon moda tasarımcıları için iktisadi kazanımlarını sağladıkları sembolik bir başkent hâline gelmiştir; ancak Japon moda tasarımcılarının Paris'te başarılı olmaları Tokyo'ya uluslararası moda alanında bir tanınırlık sağlasa da bu kenti Paris kadar ünlü bir moda merkezi hâline getirmeyi başaramamış, aksine Japonya'da moda tasarımı eğitimi alanlar Paris'e gitme hayalleri kurmaya başlamış ve kurmaktadırlar. Aslında Tokyo, günümüzde moda kentleri sıralamasında adından sıkça söz ettirmektedir; ancak bu listenin başında her zaman Paris, Londra, Milano ve New York gibi kentler bulunmakta ve yakın gelecekte ne Tokyo'nun ne de başka bir kentin dünya moda kentleri sıralamasında bu kentlerin önüne geçebileceği tahmin edilmemektedir. Bu da bazı kentlerin diğerlerine göre sembolik dolayısıyla ekonomik sermaye üretme konusunda daha şanslı olduğunu göstermektedir. 
Diğer taraftan, Fransız moda sisteminin Japon moda tasarımcılarını neden kendine dâhil ettiği sorulabilir. Moda, ortaya çıktığı zamandan beri yenilik ve yenilikçilikle ilişkilendirilmiştir (Hollander, 1993; Wilson, 1985). Moda, kendi içinde bir çelişkiyi barındırmaktadır. Bir yandan yeni olması dolayısıyla eskiye göre farklıııklarının olması gerekmekte, bir yandan da potansiyel müşterileri kaybetmemek için radikal değişimlerden uzak durmalıdır (Sproles, 1981). Japon moda tasarımcıları her ne kadar Japon olmakla ilgili bir şey yapmadıklarını, ne Batılı ne Japon olmaya çalıştıklarını söyleseler de (Koren, 1984), Batılı moda basını onları sürekli Japon olarak işaret etmektedir. Kawamura'nın (2004: 96) çalışmasında, Paris'e sözü edilen üç moda tasarımcısından sonra gelen "yeni kuşak Japon" bir tasarımcı şöyle demektedir:

Çünkü ben Japon'um, Fransızlar beni şu ünlü Japon moda tasarımcılarından biri olarak etiketlemek ya da sınılandırmak istiyorlar, ve her zaman 'tasarımların Issey'inkilere benziyor' ya da 'birkaç hafta önce Yohji'nin koleksiyonunda buna benzer bir şey görmüştüm' diyorlar. Benim sadece kopyaladığımı mı ima etmeye çalışıyorlar?

Yukarıda görüşmesinin bir bölümü alıntılanan tasarımcı, küreselleşmenin başka bir boyutuna işaret etmektedir. Fransız müşteriler ve eşik bekçileri bir yabancıdan kendi etnik kimliğine ve kültürel geçmişine yönelik üretimler beklemektedirler. Batı dışından gelen bir tasarımcı, Fransız moda sisteminde sadece bu sistemin kurallarına göre tasarımlarını oluşturduğunda Batılımoda sahnesinin gözünde diğer Batılı tasarımcılardan bir farklı kalmayacaktır. $\mathrm{Bu}$ tasarımcıdan bir yandan Fransız moda sistemine saygı duyması bir yandan da etnik kimliğine dair ayrıcalığını koruması beklenmektedir. Japon moda tasarımcıları örneğinde, ortaya çıkan tasarımlar ne tam anlamıyla Batı moda sistemi içinde yer almakta ne Japon kültürlerine ve giyim alışkanlıklarına bağlıık göstermektedir. Japon moda tasarımcıları kendi giyim kültürlerinden aldıkları unsurları Batılı moda sistemi ile uyumlulaştırmış, iki sistem arasında bir çeşit kültürel melezleşme yaşanmıştır. Paris'e sözü edilen üç moda tasarımcısından daha önce gitmiş ve kendine Fransız moda sistemi içinde yer edinen ilk Japon tasarımcı olan Kenzo Takada bunun en iyi örneklerinden biridir. Kawamura'nın (2004) aktardığına göre, Batılı eleştirmenler Kenzo'nun tasarımlarında Batılı tarzlar ile Japon baskılarının ustalıkla bir araya geldiğini ve bu tasarımların onlar için şaşırtıcı olduğunu söylemektedirler. Kenzo, egzotik olanın Batılı müşterilerin ilgisini çektiğini fark etmiş ve Japon geleneğinden gelen tarzlar ve üretim yöntemlerini 
Batılı giyim anlayışı ile bir araya getirmiştir.

Philipp W. Stockhammer (2012), melezleşmenin üç boyutu olduğunu söylemektedir. Yazara göre, melezleşmenin birinci boyutu melezleşmeyi farklı ulusların güç savaşı içinde saf ve saf olmayan ikiliğinde inşa etmektir. İkinci boyut, asimetrik güç ilişkilerinin çözümlendiği ve yapıbozuma uğratılı̆̆ı bilimsel yaklaşımın bir metaforudur. Stockhammer, son olarak, melezleşmenin kültüler arası buluşmaların analiz edilmesinin temeli olduğunun altını çizmektedir. Yazarın çağrısına kulak verip, Japon moda tasarımcıları örneğinde modadaki kültürler arası buluşmalar analiz edilebilir. Japon moda tasarımcıları ve Fransız moda sistemi arasında asimetrik bir güç ilişkisi olduğu ve sözü edilen tasarımcıların her ne kadar Batılı giyim alışkanlıklarını sorgulasalar da, özellikle Paris'de nüvelenmiş olan moda sisteminin gerekleri içinde hareket etmek zorunda oldukları akıldan çıkarılmamalıdır. Kültürel küreselleşmenin eleştirmenlerinden Aijaz Ahmad (1992) melezleşmeyi sorgusuzca kucaklayan düşünürlerin, Batı kapitalizminin maddi gücünü göz ardı ettiklerine dikkat çekmektedir. Japon moda tasarımcıları örneğinde ön plana çıkan şey, Batı'nın sadece maddi güce sahip olması değil, bunun yanında Batı'nın sosyal ve kültürel üstünlüğüne dair Batı merkezci söylemin hâlâ gücünü koruyor olmasıdır. Japon moda tasarımcıları örneğinde, Fransız moda sistemine kimin hangi şartlar altında gireceği bu sistemin kurucuları tarafından belirlenmiş̧ir; aynı zamanda bu tasarımcılara dünya çapında tanınırlık sağlayan yine Batılı moda basınıdır. Japonya'da bu tasarımcıların tasarımlarını satın alan müşteriler, Paris'te bir Japon'un bu ürünü üretmesine sevinmekte ve bundan gururlanmaktadırlar. Bu durumda, Japon kimliği, Batı tarafından onaylandıktan sonra bir gurur kaynağına dönüşmektedir.

Kültürel melezleşme ile ilgili olarak dikkat çekilmesi gereken bir başka perspektif ise, Jan Nederveen Pieterse'nin (1995) melezleşmenin hegemonik ilişkilerin yaratıldığı ve oldukları gibi kaldığı bir süreç değil, aynı zamanda bu ilişkilerin yeniden şekillendiği bir süreç olduğu yönündeki görüşüdür. Kevin Robins (1991), melezleşme sürecinde kolonileştirilen Öteki'nin Batı metropolisinin merkezine yerleştiğini söyler. Bir anlamda sömürgeleştiren, sömürgeleştirilen tarafından işgal edilmiştir. John Tomlinson (2002), kültürel küreselleşmenin kültürel değerleri yok ettiğini savının aslında geçersiz olduğunu, bunun aksine küreselleşmenin kültürel değerleri ulus devletlerin zayıflamasıyla güçlendirdiğini iddia etmektedir. Modernleşmeyle birlikte gelen ulus devlet anlayışı belirli bir toprak parçası üstünde yaşayan insan- 
Iarın hepsinin hukuk, eğitim ve medya yoluyla aynılaştırılması sürecidir aynı zamanda; ancak küreselleşme ulus devletin hem ekonomik hem kültürel dolayısıyla da sosyal ve yönetsel olarak zayıflamasına neden olmuş, birçok farklı kültüre ait ürün gerek ülkeler içinde gerekse de ülkeler dışında dolaşım imkânı bulmuştur. Japon moda tasarımcıları örneğinde, özünde kapalı bir sistem olan Fransız moda sistemi Öteki'ne açılmış, onu kendi sisteminin bir parçası kılmaya çalışmış, bu süreçte de Öteki'nin saldırılarına, eleştirilerine ve Batılı giyim alışkanlıklarını yeniden yorumlamasına tanık olmuştur. Japon moda tasarımcılarının ardından birçok farklı etnik kökenden, ulustan, kültürden gelen moda tasarımcısı koleksiyonlarını Paris'te sergilemeye başlamış, kültürel melezleşmenin birçok farklı örneğini sunmuştur.

Kawamura'nın (2004) çalışmasında yer verilen Fransız moda basınından ünlü bir eleştirmenin dediği gibi, Fransızlar Japonların Fransız moda sistemi içindeki varlığına mecburdurlar, aynı zamanda Japon moda tasarımcıları da dünya çapında bir tanınırlık elde etmek için Paris'te görünmeye mecburdur; bu ilişki basit bir şekilde bir kültürün diğerine üstünlüğü olarak değerlendirilmemelidir. Nitekim, 1990'larda ve sonrasında dünyanın moda kentleri olarak bilinen Londra, Paris, New York, Milano'ya daha birçok kent eklenmiş, en azından eklenme girişiminde bulunulmuş ve birçok kentte moda haftaları ve moda ile ilgili etkinlikler düzenlenmeye başlanmıştır.

\section{Sonuç}

Bu gelişmeleri nasıl değerlendirmek gerekmektedir? 1990'larda başlayan ve özellikle 2000 'lerde daha sıkça karşılaşır olduğumuz gelişmekte olan ülkelerin ya da bu ülkelerdeki moda tasarımcılarının ve firmaların ulusal tarihlerine ve kültürel kimliklerine vurgu yaparak uluslararası moda sahnesinde tanınırlık kazanma girişimleri onlara hangi yol ve yordamlarla bu ülke ve firmaları ekonomik alanda hâlihazırda kurumsallaşmış bir moda sistemi olan gelişmiş ülkelerle rekabet edebilecek bir duruma getirecektir? Moda sahnesinin ardında yatan etnik çatışmalar/ayrımcılıklar kültürel tanınırlık formülüyle çözümlenebilecek midir? En önemli sorulardan biri de bir sektörün gelişimi ekonomik ve sosyal hayatın diğer veçhelerindeki eşitsizliği ne ölçüde olumlu bir yöne çekecektir? Günümüzde uluslararası moda sahnesinde ulusal tarihe ve kültürel kimliğe düşürülen vurgunun ülkeler ve kentler için olumlu bir imaj oluşturan bir niteliği olduğu ve ülkelerin bu niteliği gerek finans piyasasının gerek kültür ve sanat eleştirmenlerinin gerekse de uluslararası basının ilgisini çekmek için kullanmakta hevesli olduğu görülmektedir. Ötekinin kültürel unsurlarını 
tanımak, ona doğru bir adım atmayı sağlayabileceği gibi onu karikatürize etmeyi de beraberinde getirebilir. Kültürel çeşitliliğin vurgulanması ve öne çıkartılması Batı modernleşmesinin sorgulanmasını ve çoklu modernliklerin olabileceği tartışmasını da beraberinde getirmiştir. Moda alanında görüldüğü kadarıyla bu tartışma hâlâ Batı ekseninde yapılmakta, özgün kültürler Batı moda sistemi içinde ifade olanakları bulmakta, bu sistemin dışına çıktıklarında hem ekonomik güçlerini hem de sembolik sermayelerini yitirme riski taşımaktadırlar. Japon moda tasarımcıları örneğinde, Paris moda sisteminin dışından gelerek bu sistemde kabul gören tasarımcıların etnik kimliklerine vurgu yapılarak öne çıkarıldıkları, dolayısıyla eşik bekçiliğinin ve basının etki gücünün hâlâ bu sistemin elinde olduğu görülmektedir. Öte yandan, küreselleşme olgusunun katı ve içine kapalı sistemleri dönüşüme zorladığının ve diğer sistemlerle etkileşime girmeye mecbur kıldığının altının çizilmesi gerekmektedir. Böylece, çok sesli bir kültürel alanın en azından uluslararası moda sahnesinde görünür olabildiğini söylemek yanlış olmayacaktır. Bunu göz önünde bulundurarak, kültürel küreselleşmenin en önemli getirilerinden biri olan melezleşme kavramı güçilişkileriçerçevesinde yeniden ele alınmayı beklemektedir. Gelişmekte olan ülkelerdeki moda tasarımcıları özgün kültürlerine ait unsurları egzotik bir görünüm yaratmak için kullanırken acaba oryantalist bir tuzağa mı düşmektedirler ve eğer böyleyse bu öz-oryantalist tutumun gelecekteki yansıması ne olacaktır sorusu cevaplanmayı beklemektedir. 


\section{Kaynakça}

Ahmad, A. (1992). In theory: Classes, Nations, Literatures. Londra: Verso.

Bhabha. H. (1994). The location of culture. New York: Routledge.

Bourdieu, P. (1984). Distinctions (çev. R. Nice). Londra: Routledge.

Cocks, J. (1986). "A Change of Clothes: Designer Issey Miyake Shapes New Forms into Fashion for Tomorrow", Time Magazine, Ocak, 46-52.

Craik, J. (1993). The Face of Fashion: Cultural Studies in Fashion. Londra: Routledge.

Crane, D. (2003). Moda ve Gündemleri (çev. Ö. Çelik). İstanbul: Ayrıntı Yayınları.

Davis, F. (1997). Moda, Kültür ve Kimlik (çev. Ö. Arıkan). İstanbul: Yapı Kredi Yayınları.

English, B. (2007). A Cultural History of Fashion in the Twentieth Century: From the Catwalk to the Sidewalk. New York: Bloomsbury Academics.

Featherstone, M. (2005). Postmodernizm ve Tüketim Kültürü (çev. M. Küçük). İstanbul: Ayrıntı Yayınları.

Hiramitsu, C. (2005). “Japanese Tradition in Issey Miyake”, Design Discourse, I (I), 35-43.

Hollander, A. (1993). Seeing Through Clothes. California: University of California.

Jansen, A. M. (20/3). Notions of Tradition and Modernity in the Construction of National Fashion Identities. 5th Global Fashion Conference, Oxford: Birleşik Krallık.

Kaiser, S. (2012). Fashion and Cultural Studies. Oxford: Berg.

Kawamura, Y. (2004). The Japanese Revolution in Paris Fashion. Oxford: Berg.

Koren, L. (1984). New Fashion Japan. Tokyo: Kodansha.

Massey, D. (1994). Space, Place and Gender. Cambridge: Polity.

Nederveen Pieterse, J. (1995). Globalization as Hybridization. M. Featherstone, S. Lash ve R. Robertson (Editörler). Global Modernities. Londra. Sage, s. 45-68. 
Robins, K. (I99I). Tradition and Translation: National Culture in its Global Context. J. Corner ve S. Harvey. (Editörler). Enterprise and Heritage. Londra. Routledge, s.2I-42.

Scott, A. J. (200I). "Capitalism, Cities, and the Production of Symbolic Forms", Transactions of the Institute of British Geographers, 26 (I), II-23.

Schiller, H. I. (1979). Transnational Media and National Development. K. Nordenstreng ve H. I. Schiller. (Editörler). National Sovereignty and International Communication Norwood. Ablex, s. 2I-32.

Sproles, G. B. (198I). "Analyzing Fashion Life Cycles: Principles and Perspectives”, The Journal of Marketing, 45 (4), I I6-I 24.

Steele, V. (1998). Paris Fashion: A Cultural History. Londra: Bloomsbury Academic.

Stockhammer, P. W. (20I2). Questioning Hybridity. P. W. Stockhammer. (Editör).

Conceptualizing Cultural Hybridization: A Transdiciplinary Approach. Berlin. Springer, s. 24-3I.

Teunissen, J. (2005). Global Fashion and Local Tradition. J. Brand ve J. Teunissen.

(Editörler). Global Fashion and Tradition. Utrecht. ArtEz Institute of the Arts, s.8-23.

Tomlinson, J. (2002). Globalization and Cultural Identity. D. Held ve A. McGrew. (Editörler). Global Transformations Reader. Cambridge. Polity, s. 269-277.

Tomlinson, J. (2004). Küreselleşme ve Kültür (çev. A. Eker). İstanbul: Ayrıntı Yayınları.

Vinken, B. (2005). Fashion Zeitgeist (çev. M. Hewson). New York: Berg.

Wilson, E. (1985). Adorned in Dreams: Fashion and Modernity. Londra: Virago. 